\title{
WPEYW LOKALNYCH UWARUNKOWAŃ ROZWOJU PRZEDSIĘBIORCZOŚCI NA RYNEK PRACY NA OB- SZARACH WIEJSKICH NA PRZYKŁADZIE GMIN WIEJSKICH WOJEWÓDZTWA PODKARPACKIEGO
}

\begin{abstract}
Przedsiębiorczość jako sztuka poszukiwania nowych rozwiązań i tworzenia nowych wartości, jako rodzaj aktywności człowieka odgrywa istotne znaczenie w wielu obszarach życia gospodarczego. Jej rozwój w dużym stopniu jest zależny od uwarunkowań lokalnych, osobowościowych, prawnych, ekonomicznych czy społeczno-kulturowych. Uwarunkowania lokalne, do których można zaliczyć lokalne zasoby naturalne, zasoby czynników produkcji, specyfikę rynku zbytu czy tradycję, religię, specyfikę rodziny i strukturę społeczną środowiska, są często bardzo istotnym, bezpośrednim wyznacznikiem rozwoju przedsiębiorczości lokalnej. Oprócz tych czynników nie można zapominać o tym, że to jednak człowiek (jego postawy, wiedza, skłonność podjęcia ryzyka, ambicje i aspiracje życiowe) jest głównym inspiratorem przedsiębiorczości Celem artykułu jest przedstawienie uwarunkowań lokalnych wpływających na rozwój przedsiębiorczości, a zarazem lokalnego rynku pracy na obszarach wiejskich województwa podkarpackiego. W artykule przedstawiono wyniki analiz dokonanych na podstawie danych Urzędu Statystycznego w Rzeszowie oraz badań ankietowych autora, zrealizowanych w 2011 r. wśród 1130 mieszkańców gmin wiejskich. Dla bardziej precyzyjnego odzwierciedlenia występujących zależności dotyczących analizy stanu przedsiębiorczości, stopy bezrobocia w gminach wiejskich województwa podkarpackiego gminy podzielono na trzy grupy według ich położenia: gminy w sąsiedztwie miasta, z dala od miasta oraz gminy o charakterze turystycznym. Podczas oceny stanu wiejskiego rynku pracy respondenci zostali podzieleni na pięć grup wiekowych, w przedziałach 15-18, 1925, 26-35, 36-50 oraz powyżej 50 lat.

Słowa kluczowe: rynek pracy, przedsiębiorczość, obszary wiejskie
\end{abstract}

\section{WPROWADZENIE}

Obecnie ważną rolę w kształtowaniu rynku pracy odgrywa rozwój przedsiębiorczości profilowany w dużym stopniu polityką regionalną oraz wszechobecną globalizacją.

Wpływ globalizacji na rozwój przedsiębiorczości ma dwa nurty: jasny, w którym globalizacja, dzięki demokracji i liberalizacji, prowadzi do rozwoju przedsiębiorczości i poprawy pozycji biednych społeczeństw, oraz ciemny, charakteryzujący się bezwzględną walką konkurencyjną i przewagą dużych korporacji, prowadząc do polaryzacji społeczeństw i wynikających z tego konfliktów². Globalizacja wyznacza pozycję poszczególnych regionów w ogólnokrajowej i europejskiej strukturze gospodarczo-społecznej, ukazując możliwość wykorzystania ich zasobów³ ${ }^{3}$ Jest to głównie związane z wartością doda-

\footnotetext{
${ }^{1}$ Dr inż. Marian Woźniak, Katedra Ekonomii, Wydział Zarządzania, Politechnika Rzeszowska, al. Powstańców Warszawy 8, 35-959 Rzeszów, tel.: (017) 86519 03, e-mail: mwozniak@prz.edu.pl

${ }^{2}$ H. Bieniok, Wspótczesne problemy i uwarunkowania rozwoju przedsiębiorczości, www.GlobalEconomy.pl.

${ }^{3}$ A. Czudec, Czynniki ksztattujace spójność ekonomicznq i społecznq regionu, [w:] Możliwości i bariery rozwoju regionu, red. A. Czudec, Wydawnictwo Uniwersytetu Rzeszowskiego, Rzeszów 2009, s. 13.
} 
ną wynikającą z lokalizacji oraz posiadanych zasobów regionu. Ma także bezpośredni wpływ na regionalny rynek pracy, gdyż bezrobocie stanowi jeden z najtrudniejszych problemów społeczno-gospodarczych w skali kraju. Jego waga wynika z ekonomicznego, społecznego i politycznego znaczenia tego zjawiska. Bezrobocie powoduje nie tylko straty ekonomiczne, wpływa także na duże zróżnicowanie poziomu jakości życia społeczeństwa oraz przynosi wiele negatywnych konsekwencji psychospołecznych.

Obszary wiejskie nabierają obecnie szczególnego znaczenia dla wielu aspektów życia ich mieszkańców, spełniając funkcje produkcji rolnej, a także rekreacyjno-wypoczynkowe czy kulturowe ${ }^{4}$.

Ważnym sposobem aktywizowania społeczności, a tym samym walki z bezrobociem i bezsilnością, jest podjęcie działalności gospodarczej na zasadzie własności indywidualnej lub zbiorowej. Można tutaj jednak napotykć wiele barier powodujących, że występują znaczne zahamowania w psychice i zasobach przyszłych przedsiębiorców.

\section{CEL I METODYKA PRACY}

Celem artykułu jest ukazanie wpływu lokalnych czynników, wyrażających się głównie rentą położenia, na rozwój przedsiębiorczości, a tym samym bezpośrednio kształtujących rynek pracy gmin wiejskich województwa podkarpackiego. Oceny dokonano na podstawie analiz własnych autora, do których wykorzystano:

- dane statystyczne dotyczące rynku pracy gmin wiejskich województwa na przestrzeni lat 2000-2010. Zgromadzony materiał poddano analizie statystycznej w celu znalezienia prawidłowości występujących na wiejskim rynku pracy województwa podkarpackiego. Analiza danych obejmowała:

1. Wyznaczenie wartości podstawowych miar statystycznych: średniej arytmetycznej $[\bar{x}]$, odchylenia standardowego $\left[\mathrm{s}_{\mathrm{d}}\right]$, współczynnika zmienności $\left[\mathrm{v}_{\mathrm{x}}\right]$ oraz współczynnika skośności.

2. Sprawdzenie hipotezy o normalności rozkładów wyników - testem zgodności $\chi^{2}$; wnioskowanie prowadzono przy poziomie istotności 0,05 .

3. Graficzną prezentację średniego poziomu wskaźnika w każdym z trzech typów gmin.

- badania ankietowe zrealizowane w 2011 r. wśród 1130 mieszkańców wsi podkarpackich.

W celu dokładniejszej interpretacji zjawiska podzielono gminy wiejskie województwa podkarpackiego na trzy grupy: zlokalizowane przy mieście, zlokalizowane z dala od miasta oraz gminy o charakterze turystycznym. Analizę oceny stanu wiejskiego rynku pracy dokonano także w grupach socjodemograficznych, uwzględniających wiek respondentów.

\section{UWARUNKOWANIA ROZWOJU PRZEDSIĘBIORCZOŚCI}

Bardzo istotnymi czynnikami wpływającymi na wyzwolenie motywacji przedsiębiorczego myślenia i działania są cechy osobowościowe człowieka oraz lokalne uwarunkowania rozwoju przedsiębiorczości.

\footnotetext{
${ }^{4} \mathrm{~K}$. Adamczyk, Wieś, jako miejsce życia, pracy i rehabilitacji osób niepetnosprawnych na przyktadzie Fundacji $w$ Attle, Niemcy, Prace Komisji Krajobrazu Kulturowego nr 12, Komisja Krajobrazu Kulturowego PTG, Sosnowiec 2009, s. 100-108.
} 
Podstawowym determinantem działań przedsiębiorczych jest jednak człowiek, ponieważ to on jest głównym sprawcą powstawania podmiotów gospodarczych, a jego decyzje są kształtowane uwarunkowaniami społeczno-kulturowymi, wyznaczającymi wartości, zasady i normy moralne jego postępowania, także przy tworzeniu i zarządzaniu przedsiębiorstwem.

Uwarunkowania te, co podkreśla wielu autorów, odgrywają główną rolę, gdyż przedsiębiorca nie jest zaprogramowanym robotem, lecz działa w określonej rzeczywistości, w określonym miejscu i czasie, będącym dla niego szansą lub zagrożeniem ${ }^{5}$. Wśród uwarunkowań społeczno-kulturowych można wymienić m.in.:

- religie, nawiązującą do zasad sprawiedliwości i moralności,

- rodzinę jako istotnego motywatora podejmowania działań przedsiębiorczych,

- lokalną tradycję,

- strukturę społeczną środowiska.

Na tle wartości społeczno-kulturowych i wartości człowieka jako głównego sprawcy działań przedsiębiorczych można ukazać pozostałe uwarunkowania rozwoju przedsiębiorczości, do których zalicza się przede wszystkim:

- uwarunkowania lokalne, charakteryzujące się:

- warunkami naturalnymi regionu,

- zasobami czynników produkcji,

- specyfiką rynku zbytu,

- położeniem geograficznym,

- infrastrukturą ogólną, a przede wszystkim komunikacyjna,

- dostępem do innowacji,

- oraz uwarunkowania prawne i ekonomiczne (mechanizm rynkowy, konkurencja, tempo wzrostu gospodarczego, bezrobocie).

\section{PRZEDSIĘBIORCZOŚĆ NA OBSZARACH WIEJSKICH}

W roku 2009 przedsiębiorczość na obszarach wiejskich charakteryzowała się działalnością 935,3 tys. podmiotów gospodarczych. Stanowiły one 25,0\% ogólnej liczby podmiotów wpisanych do krajowego rejestru REGON. Wskaźnik przedsiębiorczości, uwzględniający liczbę podmiotów gospodarczych na 1000 mieszkańców, był na obszarach wiejskich blisko dwukrotnie niższy niż w miastach (wynosił 63 w porównaniu ze 121 w miastach).

Analizując sytuację w poszczególnych regionach, można stwierdzić, że 2009 r. najwięcej podmiotów na obszarach wiejskich wpisano w województwie mazowieckim $(13,3 \%)$, małopolskim i wielkopolskim (po 11,5\%), najmniej zaś w województwie podlaskim $(2,4 \%)$, lubuskim $(2,6 \%)$ oraz warmińsko-mazurskim $(3,2 \%)$. W przeliczeniu na 1000 mieszkańców najwięcej podmiotów zarejestrowano w województwach zachodniopomorskim (85), pomorskim i śląskim (po 74), najmniej zaś w województwach lubelskim i podlaskim (po 47), oraz podkarpackim (49), a więc zlokalizowanych na ścianie wschodniej Polski. Bardzo podobna sytuacja występuje w odniesieniu do nowo zarejestrowanych podmiotów w 2009 r. W największym stopniu podmioty zarejestrowane na obszarach

\footnotetext{
${ }^{5}$ M. Bratnicki, B.J. Gabryś, O przedsiębiorczości raz jeszcze: w kierunku spojrzenia na wychwytywanie szans przez pryzmat interakcji komunikacyjnych, [w:] Uwarunkowania sukcesu przedsiębiorstwa, red. K. Jaremczuk, Wydawnictwo PWSZ, Przemyśl 2002, s. 229.
} 
wiejskich prowadziły działalność z zakresu handlu, naprawy pojazdów samochodowych, transportu i magazynowania, zakwaterowania i gastronomii, komunikacji oraz przemysłu i budownictwa ${ }^{6}$.

Omawiając działalność gospodarczą na obszarach wiejskich, oczywiście nie można pominąć działalności rolnej. W 2009 r. w Polsce występowało 2,5 mln gospodarstw rolnych, co stanowiło o 12,1\% mniej niż w 2003 r. W większości były to gospodarstwa o powierzchni 1-5 ha, które stanowiły 40,4\% ogólnej liczby. Na szczególną uwagę zasługuje istotny wzrost gospodarstw ekologicznych, których liczba w 2009 r. wynosiła 17,1 tys., stanowiąc ponad siedmiokrotny wzrost w odniesieniu do 2003 r. Certyfikat miało 59,4\% (10,2 tys.) gospodarstw, ich największa liczba zaś była zlokalizowana w województwach małopolskim (2197) oraz podkarpackim (2014) ${ }^{7}$.

Raport o stanie wsi w 2012 r. wskazuje, że w większości województw zmniejszył się wskaźnik zatrudnienia na wsi, co zaobserwowano także w większości krajów Unii Europejskiej, gdzie często był on większy niż w Polsce, co jednak nie zmienia faktu, że wskaźniki zatrudnienia ludności wiejskiej w Polsce są nadal niższe niż w większości krajów UE. Główne kierunki zmian, które można zaobserwować wśród pracujących na wsi w latach 2009-2011, dotyczą :

- procesu dezagraryzacji zatrudnienia, co dotyczy przede wszystkim zmniejszenia się odsetka pracujących w rolnictwie (z 13,4\% w 2009 r. do 12,8\% w 2011 r.),

- większość pracujących w rolnictwie stanowią osoby pracujące na własny rachunek,

- wśród mieszkańców wsi pracujących poza rolnictwem niski jest odsetek osób pracujących na własny rachunek,

- większość pracujących mieszkańców wsi $(58,2 \%)$ stanowią mężczyźni,

- osoby w młodszym wieku produkcyjnym stanowią 63,0\% wszystkich pracujących mieszkańców wsi,

- poprawił się poziom wykształcenia pracujących mieszkańców wsi, który wzrósł z 44,6\% w 2009 r. do 48,2\% w 2011 r., w tym z wykształceniem wyższym z 13,0\% do $15,4 \%$,

- najniższym poziomem wykształcenia cechują się mieszkańcy wsi pracujący w rolnictwie indywidualnym,

- zwiększyła się z 743 tys. w 2009 r. do 808 tys. w 2011 r. liczba bezrobotnych mieszkańców wsi. Główne kierunki zmian w tym zakresie to:

- najliczniejszą grupę bezrobotnych stanowią osoby, które straciły pracę w wyniku likwidacji stanowiska dotychczasowej pracy,

- większość bezrobotnych mieszkańców wsi to osoby z bezrolnych gospodarstw domowych,

- wśród ogółu bezrobotnych mieszkańców wsi wzrósł odsetek bezrobotnych kobiet (z 49,8\% w 2009 r. do 51,5\% w 2011 r.),

- mimo spadku z 63,7\% w 2009 r. do 62,2\% w 2011 r., w strukturze bezrobotnych mieszkańców wsi nadal przeważają osoby młode (w wieku do 34 lat),

\footnotetext{
${ }^{6}$ Obszary wiejskie w Polsce, Główny Urząd Statystyczny, Warszawa-Olsztyn 2011, s. 171-173.

${ }^{7}$ Ibidem, s. 162-163.

${ }^{8}$ I. Frenkel, Ludność wiejska, [w:] Raport o stanie wsi. Polska wieś 2012, red. J. Wilkin, I. Nurzyńska, SCHOLAR, Warszawa 2012, s. 15-35.
} 
szczególnie widoczne to jest wśród osób związanych z gospodarstwem rolnym (w 2011 r. - 81,7\%),

- większość bezrobotnych mieszkańców wsi ma zaledwie wykształcenie zawodowe $(34,3 \%)$ lub wykształcenie podstawowe $(17,1 \%)$,

- $\quad$ wzrósł odsetek bezrobotnych mieszkańców wsi trwale poszukujących pracy (z 25,8\% w 2009 r. do 33,1\% w 2011 r.),

- mała grupa bezrobotnych mieszkańców wsi ma prawo do zasiłku z tytułu bezrobocia $(16,4 \%)$,

- z 8,0\% w 2009 r. do 9,1\% w 2011 r. zwiększyła się stopa bezrobocia na obszarach wiejskich, która była wyższa wśród kobiet, wśród młodzieży w wieku 18-24 lat, osób z wykształceniem podstawowym i gimnazjalnym.

Przedsiębiorczość jako aktywność społeczeństwa wiejskiego, objawiającą się liczbą prywatnych podmiotów gospodarczych działających w gminach wiejskich województwa podkarpackiego przedstawiono tabeli 1 i na rysunku 1 .

Tabela 1. Liczba podmiotów gospodarczych sektora prywatnego

\begin{tabular}{|c|c|c|c|l|c|c|}
\hline \multirow{2}{*}{ Rok } & \multicolumn{4}{|c|}{ Miara statystyczna } & \multicolumn{2}{c|}{$\begin{array}{c}\text { Normalność } \\
\text { rozkładu }\end{array}$} \\
\cline { 2 - 7 } & $\bar{x}$ & $\mathbf{s}_{\mathbf{d}}$ & $\mathbf{v}_{\mathbf{x}}$ & Skośność & $\chi^{\mathbf{2}}$ & $\mathbf{p}_{\text {gran }}$ \\
\hline 2004 & 377,3 & 232,0 & 61,5 & 1,59 & 44,79 & 0,000 \\
\hline 2005 & 377,1 & 227,8 & 60,4 & 1,64 & 42,68 & 0,000 \\
\hline 2006 & 381,0 & 226,5 & 59,4 & 1,47 & 34,95 & 0,000 \\
\hline 2007 & 392,4 & 228,5 & 58,2 & 1,41 & 34,64 & 0,000 \\
\hline 2008 & 397,4 & 219,2 & 55,1 & 1,19 & 39,17 & 0,000 \\
\hline 2009 & 398,8 & 225,7 & 56,6 & 1,24 & 35,77 & 0,000 \\
\hline 2010 & 425,1 & 237,6 & 55,9 & 1,33 & 32,05 & 0,000 \\
\hline
\end{tabular}

Źródło: obliczenia własne na podstawie danych statystycznych uzyskanych z US w Rzeszowie.

Liczba prywatnych podmiotów gospodarczych w gminach wiejskich województwa podkarpackiego kształtowała się w badanym okresie na średnim poziomie 377,1-425,1, wykazując duże zróżnicowanie (wartości współczynnika zmienności wynoszą około $60 \%)$.

W okresie sprawozdawczości statystycznej prowadzonej przez Urząd Statystyczny w Rzeszowie w latach 2004-2010 wzrosła aktywność przedsiębiorcza społeczeństwa, przy jednoczesnych spadkach w latach 2004-2006 w gminach zlokalizowanych przy miastach oraz w roku $2008 \mathrm{w}$ gminach o charakterze turystycznym. W gminach zlokalizowanych z dala od miasta, pomimo że wykazują one najmniejszą aktywność przedsiębiorczą, widać systematyczny wzrost liczby przedsiębiorstw w latach 2004-2010. 
Rys. 1. Średni poziom podmiotów gospodarczych w trzech typach gmin w badanym okresie

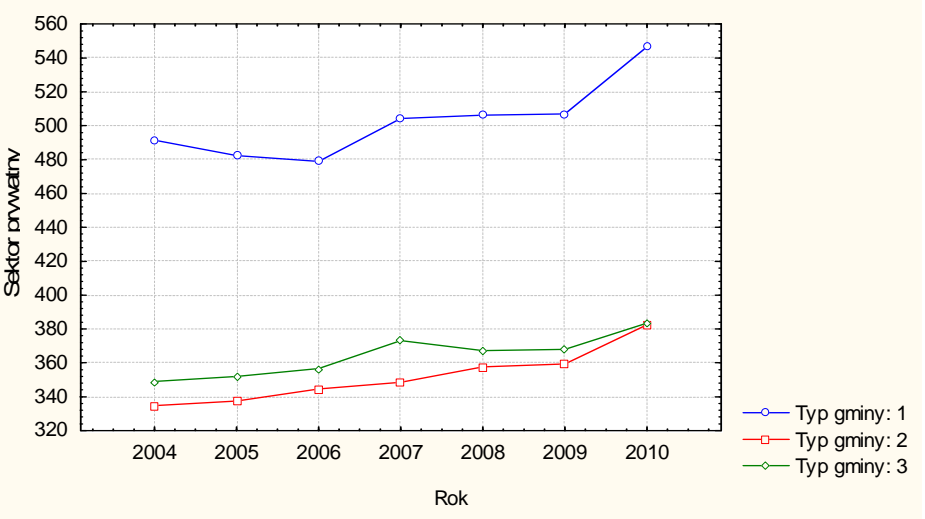

1 - gminy wiejskie zlokalizowane przy mieście; 2 - gminy wiejskie zlokalizowane $\mathrm{z}$ dala od miasta; 3 - gminy wiejskie o charakterze turystycznym

Źródło: obliczenia własne na podstawie danych statystycznych uzyskanych z US w Rzeszowie.

Na rysunku wyraźnie widać, że największy średni poziom prywatnych podmiotów gospodarczych zarejestrowano w gminach zlokalizowanych przy miastach. Jest to w dużym stopniu związane $\mathrm{z}$ położeniem gmin $\mathrm{w}$ bezpośredniej styczności $\mathrm{z}$ rynkami zbytu występującymi w ośrodkach miejskich. Dotyczy to głównie przedsiębiorczości związanej z wytwarzaniem i przetwórstwem płodów rolnych.

\section{RYNEK PRACY W GMINACH WIEJSKICH WOJEWÓDZTWA PODKARPAC- KIEGO}

Opracowania charakteryzujące specyfikę województwa podkarpackiego podkreślają, że znajduje się ono znacznie poniżej przeciętnych w Polsce. Dotyczy to przede wszystkim wskaźników aktywności gospodarczej, w tym charakteryzujących stan rolnictwa. W odniesieniu do całości obszarów wiejskich w Polsce na szczególne podkreślenie zasługują zasoby endogeniczne Podkarpacia, m.in. potencjał turystyczny ${ }^{9}$.

Jednym z głównych wskaźników ukazujących rynek pracy jest stopa bezrobocia. W tabeli 2 przedstawiono wskaźniki stopy bezrobocia w gminach wiejskich województwa podkarpackiego, na rysunku 2 zaś średni poziom stopy bezrobocia w badanych typach gmin.

\footnotetext{
${ }^{9}$ Szanse i zagrożenia oraz potencjalne kierunki rozwoju obszarów wiejskich $w$ ujęciu regionalnym, Raport podsumowujqcy, Agrotec, Warszawa 2012, s. 179.
} 
Wpływ lokalnych uwarunkowań rozwoju przedsiębiorczości... 319

Tabela 2. Stopa bezrobocia w gminach wiejskich województwa podkarpackiego

\begin{tabular}{|l|l|l|l|l|l|l|}
\hline \multirow{2}{*}{ Rok } & \multicolumn{5}{|c|}{ Miara statystyczna } & \multicolumn{2}{c|}{$\begin{array}{c}\text { Normalność } \\
\text { rozkładu }\end{array}$} \\
\cline { 2 - 8 } & $\bar{x}$ & $\mathbf{s}_{\mathbf{d}}$ & $\mathbf{v}_{\mathbf{x}}$ & Skośnośćc & $\chi^{\mathbf{2}}$ & $\mathbf{p}_{\text {gran }}$ \\
\hline 2000 & 0,175 & 0,036 & 20,5 & 0,57 & 10,42 & 0,216 \\
\hline 2001 & 0,176 & 0,039 & 22,2 & $-0,47$ & 12,04 & 0,134 \\
\hline 2002 & 0,167 & 0,035 & 20,9 & 0,04 & 5,11 & 0,275 \\
\hline 2003 & 0,185 & 0,074 & 39,7 & 0,48 & 8,23 & 0,432 \\
\hline 2004 & 0,167 & 0,061 & 36,3 & 0,95 & 9,89 & 0,076 \\
\hline 2005 & 0,159 & 0,057 & 35,9 & 0,69 & 7,19 & 0,488 \\
\hline 2006 & 0,142 & 0,052 & 36,8 & 1,02 & 14,12 & 0,066 \\
\hline 2007 & 0,122 & 0,031 & 25,8 & $-0,44$ & 12,32 & 0,137 \\
\hline 2008 & 0,124 & 0,054 & 43,6 & 0,42 & 11,64 & 0,235 \\
\hline 2009 & 0,136 & 0,043 & 31,6 & 1,02 & 7,22 & 0,065 \\
\hline 2010 & 0,138 & 0,047 & 34,1 & 0,70 & 6,79 & 0,249 \\
\hline
\end{tabular}

Źródło: obliczenia własne na podstawie danych statystycznych uzyskanych z US w Rzeszowie.

Stopa bezrobocia kształtowała się w badanym okresie na średnim poziomie 0,122 0,185, wykazując przeciętne zróżnicowanie (wartości współczynnika zmienności wynoszą od $20 \%$ do ponad $44 \%$ ).

Rys. 2. Średni poziom stopy bezrobocia w trzech typach gmin w badanym okresie

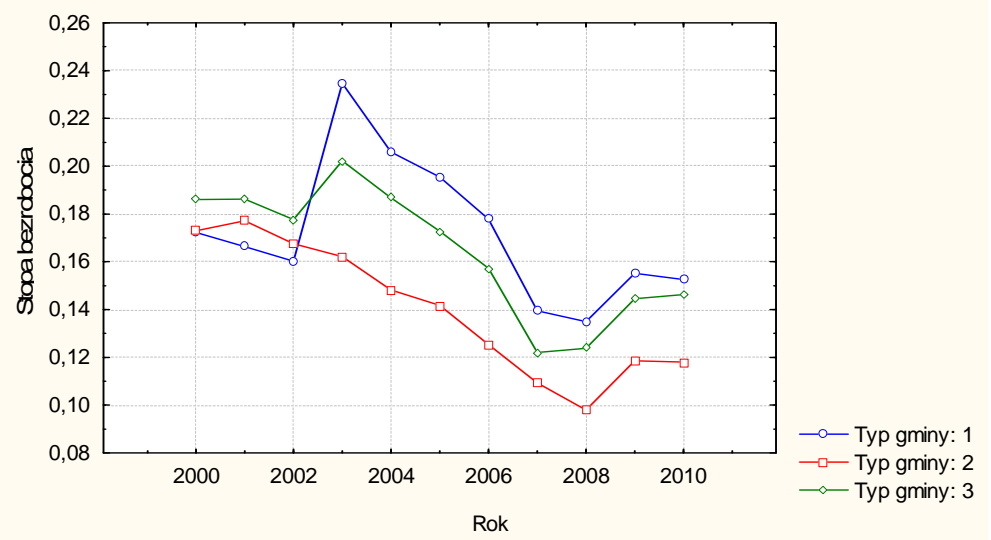

1 - gminy wiejskie zlokalizowane przy mieście; 2 - gminy wiejskie zlokalizowane $\mathrm{z}$ dala od miasta; 3 - gminy wiejskie o charakterze turystycznym

Źródło: obliczenia własne na podstawie danych statystycznych uzyskanych z US w Rzeszowie.

Analiza wyników pozwala stwierdzić, że poziom stopy bezrobocia był zróżnicowany w zależności od typu gmin i od ich lokalizacji. Poziom stopy bezrobocia w latach 20032007 we wszystkich typach gmin wykazywał wyraźny spadek. Po roku 2008 obserwujemy niewielki wzrost wskaźnika. Poziom wskaźnika był istotnie wyższy w gminach zlokalizowanych przy miastach i gminach turystycznych od poziomu bezrobocia w gminach 
zlokalizowanych z dala od miast. Może to być związane z tym, że w gminach położonych $\mathrm{z}$ dala od miast mamy w większym stopniu do czynienia $\mathrm{z}$ występowaniem bezrobocia ukrytego.

W tabeli 3 oraz na rysunku 3 przedstawiono wskaźniki ukazujące bezrobocie ukryte w gminach wiejskich województwa podkarpackiego.

Tabela 3. Bezrobocie ukryte w gminach wiejskich województwa podkarpackiego

\begin{tabular}{|l|l|l|l|l|l|l|}
\hline \multirow{2}{*}{ Rok } & \multicolumn{5}{|c|}{ Miara statystyczna } & \multicolumn{2}{c|}{$\begin{array}{c}\text { Normalność } \\
\text { rozkładu }\end{array}$} \\
\cline { 2 - 8 } & $\bar{x}$ & $\mathbf{s}_{\mathbf{d}}$ & $\mathbf{v}_{\mathbf{x}}$ & Skośność & $\chi^{\mathbf{2}}$ & $\mathbf{p}_{\text {gran }}$ \\
\hline 2000 & 0,098 & 0,056 & 56,8 & 2,08 & 66,57 & 0,000 \\
\hline 2001 & 0,090 & 0,049 & 53,9 & 1,99 & 42,88 & 0,000 \\
\hline 2002 & 0,091 & 0,049 & 54,0 & 2,08 & 51,97 & 0,000 \\
\hline 2003 & 0,091 & 0,052 & 56,9 & 2,20 & 63,08 & 0,000 \\
\hline 2004 & 0,090 & 0,051 & 56,5 & 2,16 & 65,17 & 0,000 \\
\hline 2005 & 0,091 & 0,051 & 56,6 & 2,25 & 63,58 & 0,000 \\
\hline 2006 & 0,090 & 0,051 & 56,2 & 2,19 & 44,59 & 0,000 \\
\hline 2007 & 0,091 & 0,052 & 56,8 & 2,03 & 68,54 & 0,000 \\
\hline 2008 & 0,093 & 0,052 & 56,5 & 1,83 & 53,26 & 0,000 \\
\hline 2009 & 0,092 & 0,044 & 48,0 & 1,58 & 48,77 & 0,000 \\
\hline 2010 & 0,096 & 0,050 & 52,2 & 2,34 & 29,22 & 0,000 \\
\hline
\end{tabular}

Źródło: obliczenia własne na podstawie danych statystycznych uzyskanych z US w Rzeszowie.

Poziom bezrobocia ukrytego kształtował się w badanym okresie na średnim poziomie 0,090-0,098, wykazując duże zróżnicowanie (wartości współczynnika zmienności wynoszą ponad $48 \%$ ).

Rys 3. Średni poziom bezrobocia ukrytego w trzech typach gmin w badanym okresie

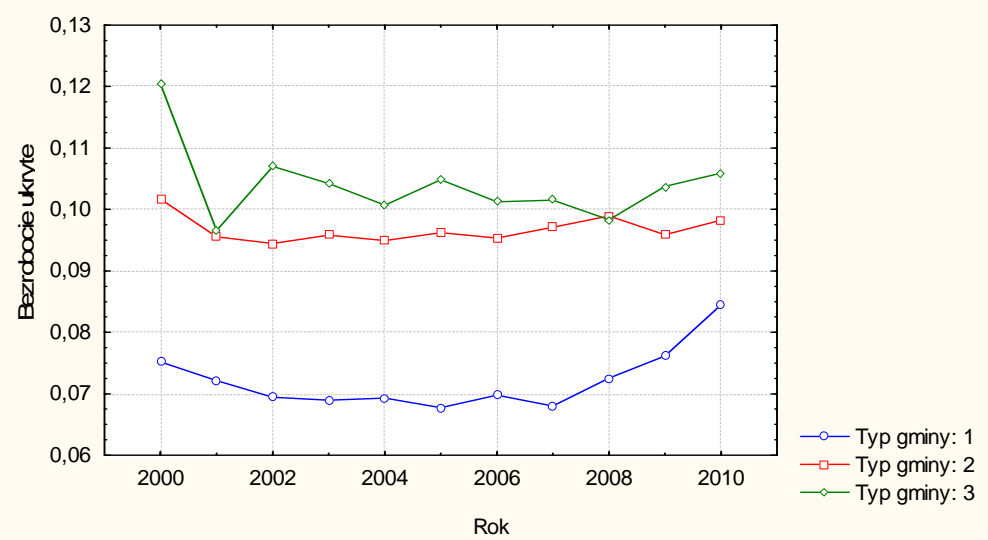

1 - gminy wiejskie zlokalizowane przy mieście;2 - gminy wiejskie zlokalizowa-

ne $\mathrm{z}$ dala od miasta; 3 - gminy wiejskie o charakterze turystycznym

Źródło: obliczenia własne na podstawie danych statystycznych uzyskanych z US w Rzeszowie. 
Analiza wyników dotyczących bezrobocia ukrytego ukazuje, że w latach 2000-2010 największy wzrost wskaźnika odnotowano $\mathrm{w}$ gminach zlokalizowanych przy miastach, przy jednoczesnym podkreśleniu, że poziom tego wskaźnika w tych gminach jest znacznie niższy od poziomu w gminach pozostałych. Największy jego poziom dotyczy gmin o charakterze turystycznym oraz zlokalizowanych $\mathrm{z}$ dala od miasta, a więc $\mathrm{w}$ gminach w dużym stopniu o charakterze rolniczym.

Ważnym aspektem ukazującym obraz obecnej polskiej wsi jest analiza sytuacji społeczno-gospodarczej po wstapieniu do Unii Europejskiej, gdzie jedni wiązali z tym wydarzeniem duże nadzieje, drudzy zaś wyrażali wielkie obawy, że nie poradzimy sobie na europejskim rynku. Rzeczywistość pozytywnie zweryfikowała te opinie, a nasze rolnictwo stało się nowocześniejsze, a wieś bogatsza ${ }^{10}$. Istotnym wskaźnikiem oceny stanu rynku pracy jest analiza zjawiska w okresie przed akcesją do UE i po niej, co przedstawiono w tabel 4.

Tabela 4. Stan rynku pracy przed akcesją do UE i po niej w gminach wiejskich województwa podkarpackiego - wyniki dwuczynnikowej analizy wariancyjnej

\begin{tabular}{|l|l|l|l|l|l|}
\hline \multirow{2}{*}{ Typ gminy } & \multirow{2}{*}{ Okres } & \multicolumn{1}{|c|}{$\begin{array}{c}\text { Pracujący } \\
\text { ogółem }\end{array}$} & \multicolumn{1}{|c|}{$\begin{array}{c}\text { Udzial } \\
\text { kobiet }\end{array}$} & $\begin{array}{c}\text { Stopa bez- } \\
\text { robocia }\end{array}$ & $\begin{array}{c}\text { Bezrobocie } \\
\text { ukryte }\end{array}$ \\
\cline { 3 - 6 } & \multicolumn{4}{|c|}{$\bar{x}$} \\
\hline $\begin{array}{l}\text { Gminy wiej- } \\
\text { skie zlokali- } \\
\text { zowane przy } \\
\text { mieście }\end{array}$ & Przed & 681,6 & 49,13 & 0,185 & 0,071 \\
\cline { 2 - 6 } & Po & 758,7 & 49,74 & 0,134 & 0,087 \\
\hline $\begin{array}{l}\text { Gminy wiej- } \\
\text { skie zlokali- } \\
\text { zowane z dala } \\
\text { od miasta }\end{array}$ & Przed & 601,3 & 52,21 & 0,166 & 0,097 \\
\cline { 2 - 6 } $\begin{array}{l}\text { Gminy wiej- } \\
\text { skie o charak- } \\
\text { terze tury- } \\
\text { stycznym }\end{array}$ & Po & 630,4 & 52,92 & 0,118 & 0,098 \\
\cline { 2 - 6 } & Po & 439,8 & 50,23 & 0,188 & 0,106 \\
\hline
\end{tabular}

Źródło: obliczenia własne na podstawie danych statystycznych uzyskanych z US w Rzeszowie.

Analiza stanu rynku pracy przed akcesją do UE i po niej pozwala stwierdzić, że:

- wartości średniej arytmetycznej wskazują na to, że najwyższy poziom wskaźnika pracujących ogółem (zarówno w okresie przed-, jak i poakcesyjnym) wystąił w gminach wiejskich zlokalizowanych przy mieście, niższy - w gminach wiejskich zlokalizowanych $\mathrm{z}$ dala od miasta, a najniższy - w gminach wiejskich o charakterze turystycznym. Widać tutaj istotne różnice przed akcesją do UE i po niej, gdzie we wszystkich typach gmin nastąpił wzrost wskaźnika w roku 2010 w stosunku do roku 2004,

- w wypadku udziału kobiet wśród pracujących nie zaobserwowano we wszystkich typach gmin istotnych różnic w badanych okresach,

\footnotetext{
${ }^{10}$ Wspólna Polityka Rolna a polska wieś, 27 sierpnia - 2 września 2012 r., www.zielonysztandar.com.pl, s. 9.
} 
- wartości średniej arytmetycznej dla stopy bezrobocia wskazują na to, że we wszystkich typach gmin zanotowano w okresie poakcesyjnym średnio niższą stopę bezrobocia niż w okresie przedakcesyjnym, co świadczy o pozytywnym wpływie integracji na rynek pracy badanych gmin, niezależnie od ich położenia,

- wartości średniej arytmetycznej dla bezrobocia ukrytego wskazują na to, że integracja europejska w niewielkim stopniu miała wpływ na wielkość tego wskaźnika.

W odniesieniu do statystycznych wskaźników ukazujących rynek pracy gmin wiejskich województwa podkarpackiego można przedstawić wyniki analizy badań ankietowych dotyczących oceny wiejskiego rynku pracy w opinii mieszkańców wsi (tab. 5, 6).

Tabela 5. Ocena stanu wiejskiego rynku pracy w swoim środowisku w zależności od typu gminy (wyniki analizy wariancyjnej, ocena w skali 1-5, gdzie 1 - ocena najniższa, 5 - ocena najwyższa)

\begin{tabular}{|l|r|c|}
\hline Typ gminy & $\bar{x}$ & $\mathbf{s}_{\mathbf{d}}$ \\
\hline Gminy wiejskie zlokalizowane przy mieście & 2,45 & 1,10 \\
\hline Gminy wiejskie zlokalizowane z dala od miasta & 2,26 & 1,02 \\
\hline Gminy wiejskie o charakterze turystycznym & 2,22 & 1,10 \\
\hline
\end{tabular}

Źródło: obliczenia własne na podstawie badań ankietowych.

Analiza wariancyjna wykazała istotny statystycznie wpływ typu gminy na ocenę wiejskiego rynku pracy w swoim środowisku. Ocena wiejskiego rynku pracy jest istotnie wyższa wśród mieszkańców gmin wiejskich zlokalizowanych przy mieście w porównaniu z opinią mieszkańców gmin wiejskich zlokalizowanych z dala od miasta i gmin wiejskich o charakterze turystycznym.

Tabela 6. Ocena stanu wiejskiego rynku pracy w swoim środowisku w zależności od wieku respondenta (wyniki analizy wariancyjnej, ocena w skali 1-5, gdzie 1 - ocena najniższa, 5 ocena najwyższa)

\begin{tabular}{|l|l|l|l|l|l|l|l|l|}
\hline \multirow{2}{*}{ Wiek } & \multicolumn{2}{|c|}{$\begin{array}{c}\text { Wszyscy } \\
\text { respondenci }\end{array}$} & \multicolumn{2}{|c|}{$\begin{array}{c}\text { Gminy wiejskie } \\
\text { zlokalizowane } \\
\text { przy mieście }\end{array}$} & \multicolumn{2}{|c|}{$\begin{array}{c}\text { Gminy wiejskie } \\
\text { zlokalizowane } \mathbf{z} \\
\text { dala od miasta }\end{array}$} & $\begin{array}{c}\text { Gminy wiejskie } \\
\text { o charakterze } \\
\text { turystycznym }\end{array}$ \\
\cline { 2 - 10 } & $\bar{x}$ & $\mathbf{s}_{\mathbf{d}}$ & $\bar{x}$ & $\mathbf{s}_{\mathbf{d}}$ & $\bar{x}$ & $\mathbf{s}_{\mathbf{d}}$ & $\bar{x}$ & $\mathbf{s}_{\mathbf{d}}$ \\
\hline $15-18$ & 2,55 & 1,11 & 2,64 & 1,17 & 2,42 & 0,98 & 2,63 & 1,31 \\
\hline $19-25$ & 2,45 & 1,03 & 2,59 & 1,05 & 2,36 & 0,98 & 2,27 & 1,04 \\
\hline $26-35$ & 2,29 & 1,05 & 2,43 & 1,07 & 2,09 & 1,03 & 2,37 & 1,04 \\
\hline $36-50$ & 2,23 & 1,03 & 2,34 & 1,01 & 2,20 & 1,01 & 1,98 & 1,14 \\
\hline$>50$ & 2,25 & 1,17 & 2,25 & 1,26 & 2,34 & 1,10 & 2,13 & 1,10 \\
\hline
\end{tabular}

Źródło: obliczenia własne na podstawie badań ankietowych.

Ocena wiejskiego rynku pracy w swoim środowisku jest istotnie wyższa wśród respondentów grupy wiekowej 15-25 lat w porównaniu z pozostałymi grupami wiekowymi. Analiza wariancyjna sytuacji w poszczególnych grupach gmin wykazała brak istotnego statystycznie wpływu wieku na ocenę stanu wiejskiego rynku pracy w swoim środowisku. Jednak przypatrując się średnim ocenom, widać, że we wszystkich grupach najlepiej sytuację na wiejskim rynku pracy oceniły osoby młode, w wieku 15-18 lat. Może to być 
związane $\mathrm{z}$ tym, że osoby te w większości jeszcze się uczą i nie mają doświadczenia z zakresie poszukiwania pracy.

\section{PODSUMOWANIE}

Uwarunkowania lokalne związane z położeniem gminy odgrywają ważną rolę w kształtowaniu lokalnej przedsiębiorczości, która jest silnie skorelowana z rozwojem regionu. W związku z tym istotne jest wspieranie aktywności przedsiębiorców poprzez rozwijanie sprzyjających warunków, które będą determinowały rozwój przedsiębiorczości. Ma to szczególne znaczenie w regionach słabiej rozwiniętych, do których zalicza się gminy wiejskie województwa podkarpackiego. Badania pozwalają sformułować następujące wnioski:

- lokalizacja gminy ma istotny wpływ na rozwój przedsiębiorczości, co można zaobserwować głównie w gminach wiejskich położonych w sąsiedztwie ośrodków miejskich,

- wejście Polski w struktury Unii Europejskiej doprowadziło w województwie podkarpackim do istotnego wzrostu liczby pracujących ogółem oraz zmniejszenia stopy bezrobocia we wszystkich typach analizowanych gmin,

- najwyżej stan wiejskiego rynku pracy oceniają ogółem mieszkańcy gmin położonych w sąsiedztwie miast, przy czym we wszystkich typach gmin najlepsze oceny, mieszczące się jednak zaledwie na poziomie 2,64-2,42, wystawiły osoby młode, które najprawdopodobniej nie zetknęły się jeszcze na dobre $\mathrm{z}$ realiami rynku pracy w miejscu zamieszkania.

\section{LITERATURA}

[1] Adamczyk K., Wieś, jako miejsce życia, pracy i rehabilitacji osób niepetnosprawnych na przyktadzie Fundacji w Attle, Niemcy, Prace Komisji Krajobrazu Kulturowego Nr 12, Komisja Krajobrazu Kulturowego PTG, Sosnowiec 2009.

[2] Bieniok H., Wspótczesne problemy $i$ uwarunkowania rozwoju przedsiębiorczości, www.GlobalEconomy.pl.

[3] Bratnicki M., Gabryś B.J., O przedsiębiorczości raz jeszcze: w kierunku spojrzenia na wychwytywanie szans przez pryzmat interakcji komunikacyjnych, [w:] Uwarunkowania sukcesu przedsiębiorstwa, red. K. Jaremczuk, Wydawnictwo PWSZ, Przemyśl 2002.

[4] Czudec A., Czynniki kształtujace spójność ekonomicznq i społecznq regionu, [w:] Możliwości i bariery rozwoju regionu, red. A. Czudec, Wydawnictwo Uniwersytetu Rzeszowskiego, Rzeszów 2009.

[5] Frenkel I., Ludność wiejska, [w:] Raport o stanie wsi, Polska wieś 2012, red. J. Wilkin, I. Nurzyńska, SCHOLAR, Warszawa 2012.

[6] Obszary wiejskie w Polsce, Główny Urząd Statystyczny, Warszawa-Olsztyn 2011.

[7] Szanse i zagrożenia oraz potencjalne kierunki rozwoju obszarów wiejskich w ujęciu regionalnym, Raport podsumowujacy, Agrotec, Warszawa 2012.

[8] Wspólna Polityka Rolna a polska wieś, 27 sierpnia - 2 września 2012 r., www.zielonysztandar.com.pl. 


\section{THE IMPACT OF LOCAL CONDITIONS ON DEVELOPMENT OF ENTREPRE- NEURSHIP IN THE LABOR MARKET IN RURAL AREAS ON THE EXAMPLE OF PODKARPACIE PROVINCE}

An important way to activate communities and to fight against unemployment and helplessness is starting a business based on the individual or collective ownership. There are, however, many barriers that are a significant inhibition in the minds and resources to entrepreneurs. Very important factors affecting the release of motivation for entrepreneurial thinking and action are the personality traits of a human, as well as local conditions for the development of entrepreneurship. The primary determinant of entrepreneurial activities is however a man, because he is the main culprit of the formation of business entities and its decisions are determined by the socio-cultural determinants which are defining the values, principles and ethical standards shaping his activity also during the time of enterprise creation and management.

Entrepreneurship as "art" of searching new solutions and creating new values as a kind of human activity plays an important role in many areas of the economy. Its development is largely dependent on local, personal, legal, economic and socio-cultural circumstances. Local conditions are often very significant, direct determinant of local entrepreneurship development. This article presents the local conditions affecting the development of entrepreneurship and also the local labor market in rural areas of Podkarpacie Province.

In article the survey results will be presented. The researches have been carried out in the year 2011 among 1130 residents of rural communities. To reflect more accurately the existing dependencies the communities have been divided into three groups according to the location.

Keywords: the labor market, entrepreneurship, rural areas

DOI: 10.7862/rz.2013.mmr.64

Tekst złożono w redakcji: wrzesień 2013

Przyjęto do druku: grudzień 2013 